\title{
HALLÓKÉSZÜLÉKEK, COCHLEÁRIS IMPLANTÁTUMOK
}

\author{
Szarka Ádám \\ BSc géptervezö hallgató, Miskolci Egyetem \\ Gép- és Terméktervezési Intézet \\ 3515 Miskolc, Miskolc-Egyetemváros, e-mail: szarkaadam09@gmail.com \\ Bihari Zoltán \\ egyetemi docens, Miskolci Egyetem \\ Gép- és Terméktervezési Intézet \\ 3515 Miskolc, Miskolc-Egyetemváros, e-mail: machbz@uni-miskolc.hu
}

\begin{abstract}
Absztrakt:
Ez a gyüjtömunka az emberi fül felépitéséröl, a hallás müködéséröl, a halláskárosodás fajtáiról, valamint annak hallókészülékkel és implantátummal való javitásáról szól. Ezen túl ismerteti az egyes hallókészülékek, implantátumok kiválasztását megelőzö vizsgálatokat, a készülékek típusait, részeit, müködését és egyéb funkcióit. Tárgyalja továbbá az implantátum beültetésének menetét és beüzemelésének folyamatát.
\end{abstract}

Kulcsszavak: Implantátum, siketség, halláskárosodás, hallókészülék

\begin{abstract}
:
This article is about the structure of the human ear, the method of hearing, the different types of hearing loss, and treatment of hearing loss with different types of hearing aids and implants. It also discusses the selection process of hearing aids, including preliminary examinations, the types, elements, functions and the operating principle of hearing aids. Furthermore it discusses the implantation process and programming of cochlear implants.
\end{abstract}

Keywords: Implant, deafness, hearing loss, hearing aid

\section{Bevezetés}

Az emberi test 5 érzékszervvel rendelkezik. Ezek a szem, bőr, orr, nyelv és a fül. A fülünk a hallás érzékszerve. A hallóképesség valamely élőlény hallószervének a hangfelfogó képességét jelenti. A hallóképesség fontos szerepet játszik a beszéd hallásán kívül a tájékozódásban. A hallás romlása vagy megszünése esetén nem halljuk a közeledő jármüvek hangját, egyéb zajjal járó potenciálisan veszélyt rejtő eseményeket, ezért a hallóképesség hiánya a biztonságérzetünkre is negatívan hat. Az átlagos emberi hallóképesség a technológia fejlődésével egyre romlott. A puskapor feltalálása és az ipari forradalom nagyságrendekkel nagyobb zajterhelést jelentett az előző évszázadokhoz képest. A halláskárosodás bekövetkeztének sokféle oka lehet: fertőző betegségek, a hallószerv fizikai sérülése, gyógyszerek mellékhatásai, öregedés, öröklött hajlam. A halláskárosodást hallásvizsgálat során mérik fel audiogram készítésével. Az audiogram a hallásküszöb decibeles megjelenítése a frekvencia 
függvényében. A hallásküszöb az a legkisebb intenzitású hang, amit a vizsgált személy még éppen érzékel. Halláskárosult az a személy, akinek a hallásérzékenysége rosszabb, mint egy egészséges fiatal felnőtté. A halláskárosodást öt csoportba lehet sorolni [1]:

- „Enyhe $(25-40 \mathrm{~dB})$

- Mérsékelt (41-55 dB)

- Mérsékelten Súlyos (56-70 dB)

- Súlyos (71-90 dB)

- Teljes (90 dB felett)"

Siketnek számít az egyén, akinek 90 dB feletti a hallásvesztése, valamint hallása hallókészülékkel sem korrigálható.

\section{Halláskárosultak a történelemben [2]}

Kr.e. 364.: Arisztotelész azt állította, hogy a „siketek képtelenek önállóan döntéseket hozni” valamint, hogy ,a vakok intelligensebbek, mint a siketek”.

Kr.e.355.: Az ókori görögök megtagadták a siketek számára az oktatást. Arisztotelész úgy gondolta, hogy „a siketeket nem lehet oktatni hallás nélkül, képtelenek tanulni” valamint „a siketek értelmetlenek és logikus döntésekre képtelenek". A görögök a görög nyelvet tökéletesnek gondolták, ezért bárkit, aki nem beszélte a nyelvet, barbárnak gondolták, így a siketek is barbárnak számítottak.

738-ban I. Iusztinianosz bizánci császár kijelentette, hogy a siketség és némaság két különböző tulajdonság és nem mindig egyszerre vannak jelen. Ezt a kijelentést kifejezetten a halláskárosult bizánci polgárok érdekében tette, akik korlátozott jogokkal bírtak.

A középkorban a siket emberek megszégyenítés áldozatává váltak, valamint bolondok házába zárták őket, mert démonok által megszállottként tekintettek rájuk.

Az 1500-as években Geronimo Cardano volt az első orvos, aki felismerte a siketek logikus gondolkodásának képességét, és elkezdte halláskárosult fiát szimbólumok segítségével oktatni.

1550-ben Pedro Ponce de León az első tanító a siketség történelmében, aki kialakított egy jelnyelvet, ezzel sikeresen tanítva siketeket egészen születésüktől fogva. Pedro Ponce sikerrel tanított meg siket diákokat beszélni, olvasni és írni Spanyolországban, valamint feltételezhető, hogy az ö módszerei hatására adta ki Juan Pablo Bonet 1620-ban az első könyvet a „Kézi ábécé jelek a siketek számára" címmel. Juan Pablo Bonet könyvét Angliában csupán 200 évvel később, 1885-ben adták ki „Az ábécé betűinek egyszerüsítése és a siket-némák tanításának módszere” címmel. Ez a könyv nagy hatással volt a siketek oktatásának elterjedésében Európában.

1640-ben George Dalgamó egy teljesen új nyelvi rendszert javasolt a siket-némák számára, amit a mai napig használnak az Egyesült Államokban.

1755-ben Samuel Heinicke volt a siketek első szájról olvasást oktató tanára, aki az első szájról olvasó módszertanú iskolát alapította a siketek számára.

1872-ben Alexander Graham Bell népszerüsíti a siketek oktatását és iskolát alapít ebben az évben. Ugyanakkor Bell a szájról olvasás híve volt.

1892-ben feltalálják az elektromos hallókészüléket.

1964-ben Robert Weitbrecht elkészíti a tele printert, egy vezetékes telefonhálózatot használó berendezést, amellyel süketek és beszédzavaros emberek is kommunikálhatnak egymással billentyüzeten és kijelzőn keresztül.

1995-ben jóváhagyják a cochleáris implantátumok beültetését felnőttek részére. 


\section{Az emberi fül felépítése és müködése}

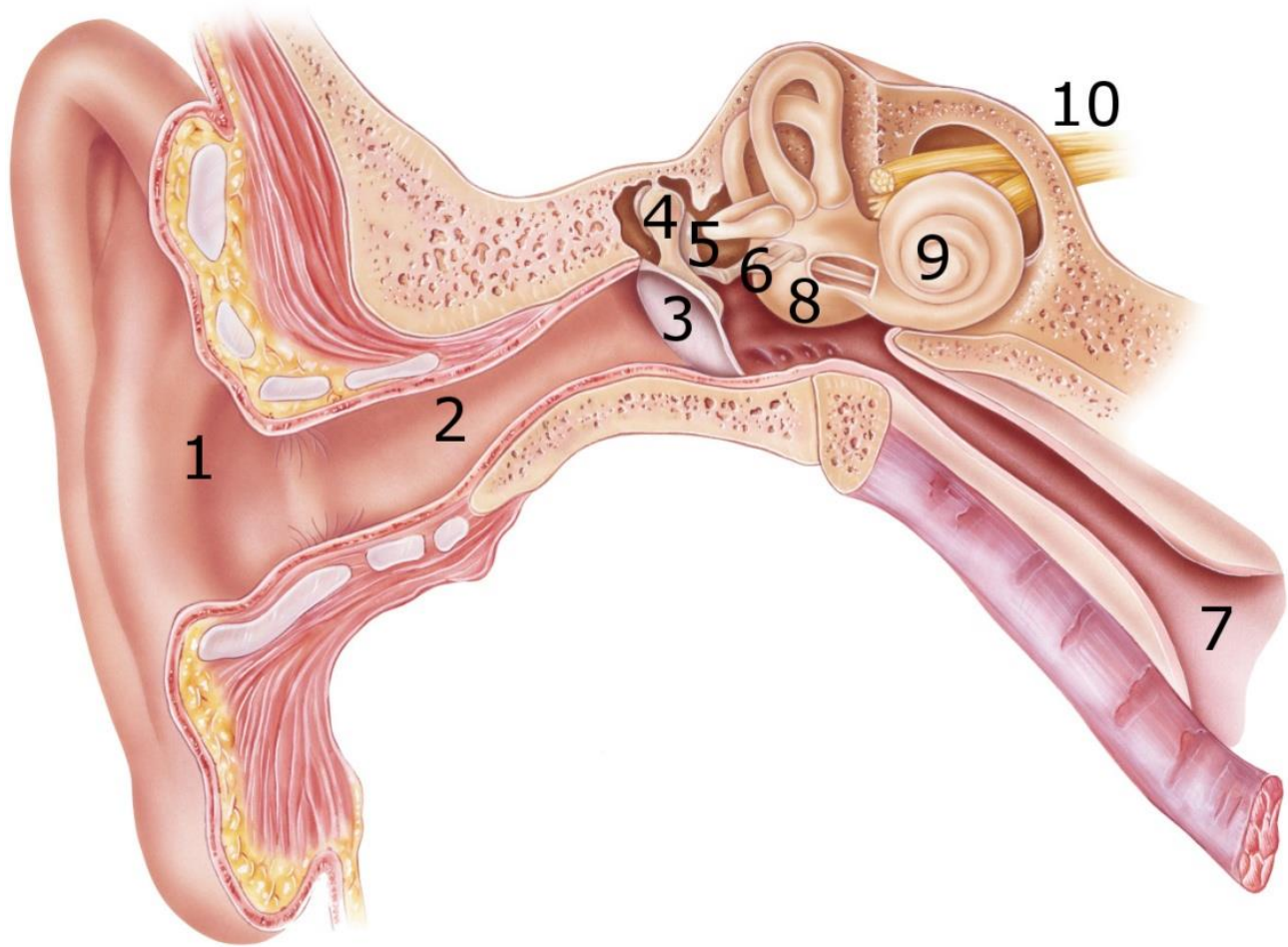

1. ábra. Az emberi fül részei [3]

Az emberi fül részei az 1-es ábra szerint: 1. fülkagyló 2. hallójárat 3. dobhártya 4. kalapács 5. üllő 6 . kengyel 7. fülkürt 8 . baziláris membrán 9 . csiga 10 . hallóideg, egyensúlyideg.

A fül részei három fö csoportba sorolhatók [4]:

- külső fül: fülkagyló, külső hallójárat, dobhártya;

- középső fül: kalapács, üllőcsont, kengyel, fülkürt;

- belső fül: csiga, baziláris membrán, hallóideg, egyensúlyideg.

\subsection{Az emberi fül müködése [5]}

A hallás a levegőben terjedő hanghullámok elektromos jellé alakításán alapszik:

1. A hanghullámok bejutnak a fülkagylóba, áthaladnak a hallójáraton, majd eljutnak a dobhártyáig.

2. A beérkező hanghullámoktól a dobhártya rezegni kezd, ennek hatására továbbítja a rezgést három apró csontnak a középső fülben: a kalapácsnak, üllőcsontnak és kengyelnek.

3. A kalapács, üllőcsont és a kengyel felerösítik a beérkező hanghullámokat és a belső fülben lévő csigának továbbítják. A csiga egy folyadékkal telt része a fülnek, amelyben egy rugalmas válaszfal húzódik a csiga elejétől a végig, ily módon egy alsó és felső részre osztva azt. Ezt a rugalmas válaszfalat baziláris membránnak nevezik, alakját a 2-es ábra mutatja be. 


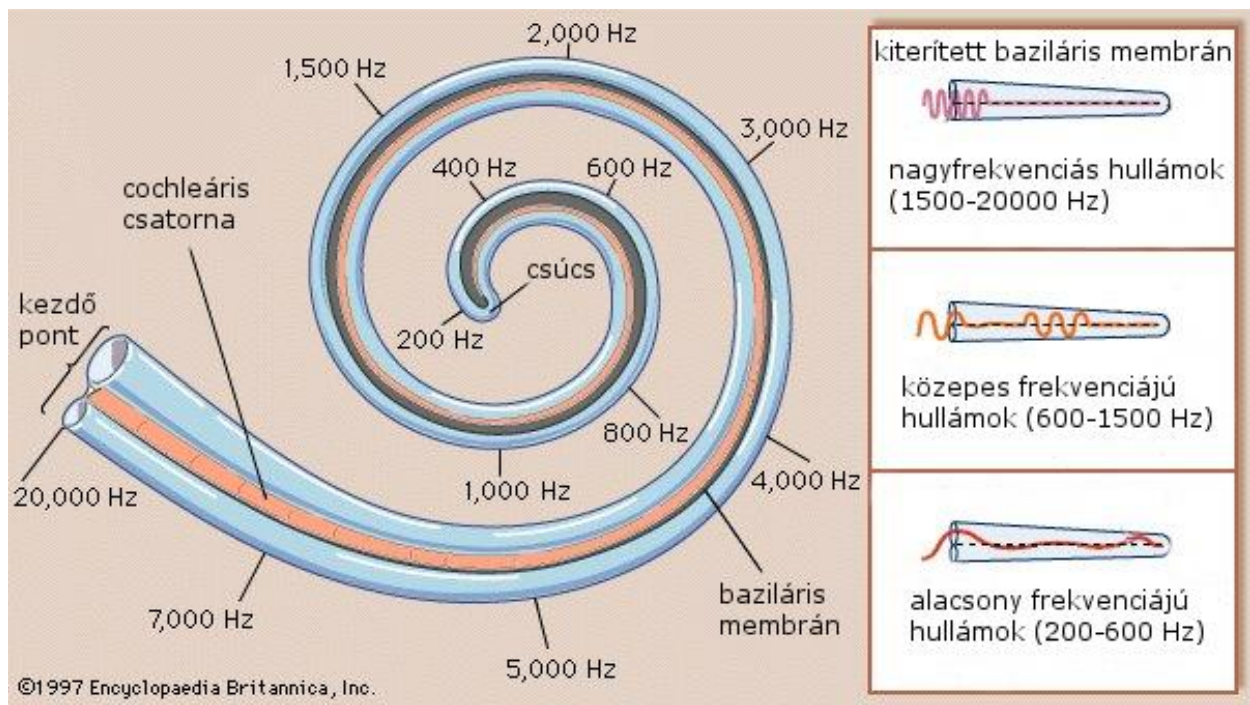

2. ábra. A baziláris membrán frekvencia érzékelése [6]

4. A csontok által keltett rezgések a csigában lévő folyadékot megmozgatják a baziláris membrán mentén. Ezek a folyadékhullámok a baziláris membránon lévő kis csillószőröket megmozgatják, és villamos kisüléshez hasonló jelenség révén elektromos jeleket hoznak létre. A csiga bemenő, széles részén lévő érzékelő sejtek a magas hangokat, míg a csiga középső, szükebb részén a mélyebb hangokat érzékelik.

5. A hallóideg elszállítja az elektromos jelet az agyig, az agy pedig átalakítja ezt a jelet hanggá, amit érzékelünk.

\section{A halláskárosodás típusai [7]}

Hang-feldolgozási rendellenesség: az agy nem tudja feldolgozni a hangokat, ezáltal nem képes értelmezni a beszédet, valamint a hangok irányát sem tudja behatárolni.

Vezetéses halláskárosodás: a külső és középső fül valamilyen oknál fogva akadályozza a hang eljutását a belső fülbe. Ennek oka lehet felhalmozódott fülzsír a hallójáratban, fülfertőzés okozta folyadékfelgyülemlés a középső fülben, kilyukadt dobhártya vagy csontkinövés a középső fülben. Ez a típusú hallászavar gyermekeknél fordul elő gyakran.

Idegi központú halláskárosodás: a belső fülben lévő csiga vagy a hallóideg sérülése miatt nem jutnak el az elektromos jelek az agyhoz. Az idegi központú halláskárosodás a legtöbb esetben nem javítható. A kiváltó ok lehet genetikai, fertőzés, baleset, károsan hangos hangok, vegyszerek, gyógyszerek vagy az öregedés is.

Kevert halláskárosodás: amikor az idegi központú és vezetéses halláskárosodás egyszerre van jelen, akkor kevert halláskárosodásról beszélünk. Ekkor az idegi központú halláskárosodás maradandó, a vezetéses halláskárosodás lehet maradandó vagy átmeneti. Például ha egy időskori halláskárosodást szenvedett egyén fülfertőzést kap, akkor már kevert halláskárosodásról beszélünk. 


\section{Hallókészülékek [8]}

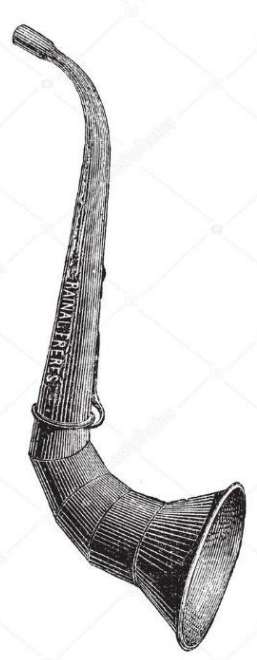

3. ábra. Fém fültrombita [9]

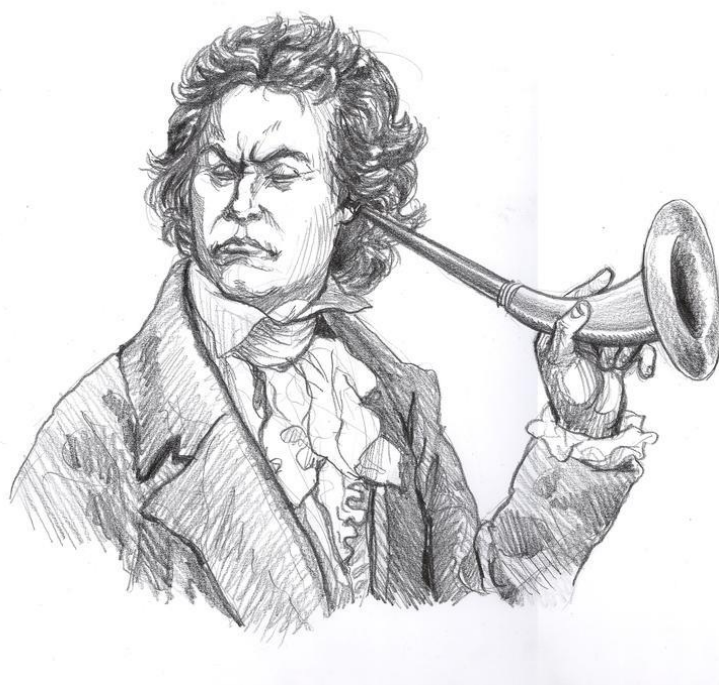

4. ábra. Fültrombita használata [10]

A mai modern elektromos hallókészülékek ősét 1892-ben készítették el, az ezt megelöző évezredekben csak kezdetleges hallássegítő eszközöket alkalmaztak. Eleinte állatok szarvát faragták üregesre, majd a hallójárat nyílásához tartották, így összegyüjtve és a fülbe vezetve a hangokat. Későbbiekben fémből készítettek azonos elven müködő fültrombitát. Ezen eszközök hallásjavítása egy mai modern elektroakusztikus hallókészülékhez képest elhanyagolható volt. A fémböl készült fültrombita a 3-as, használata a 4-es ábrán látható.

\subsection{Modern hallókészülékek}

\section{Halláskárosodás felmérése [11]}

A hallókészülék kiválasztását egy hallásvizsgálat előzi meg, ahol a hallásspecialista elkészíti a páciens audiogramját. Az audiogram egy grafikon, amely megmutatja, hogy a vizsgált személy a 125$8000 \mathrm{~Hz}-$ es frekvencia tartományon belül milyen hangerejü hangokat hall a mínusz $10 \mathrm{~dB}$ és a plusz 120dB-es tartományban. Ilyen módon feltérképezik a páciens hallásküszöbét. Egy elkészített audiogram az 5. ábrán látható. Az audiogramban minél távolabb van a mért érték a $0 \mathrm{~dB}$-es értéktől, annál rosszabb a hallása a mért személynek. Ha a páciens hallásgörbéje a $30 \mathrm{~dB}$-es érték alatt húzódik, akkor már beszédértési problémai vannak. Az audiogramot (5. ábra) audiométerrel készítik el (6. ábra). A hallókészülékek fejlett digitális technológiát alkalmazó készülékek, amelyek javítják azon hangok hallhatóságát, amelyek egyéb esetben érthetetlenek lennének a készüléket nem viselő számára.

$\mathrm{Az}$ Országos Egészségügyi Pénztár támogatást biztosít a hallókészülékekre érvényes Társadalombiztosítási Azonosító Jellel rendelkezők részére. A legolcsóbb készülékekre a támogatás mértéke $70 \%$. 


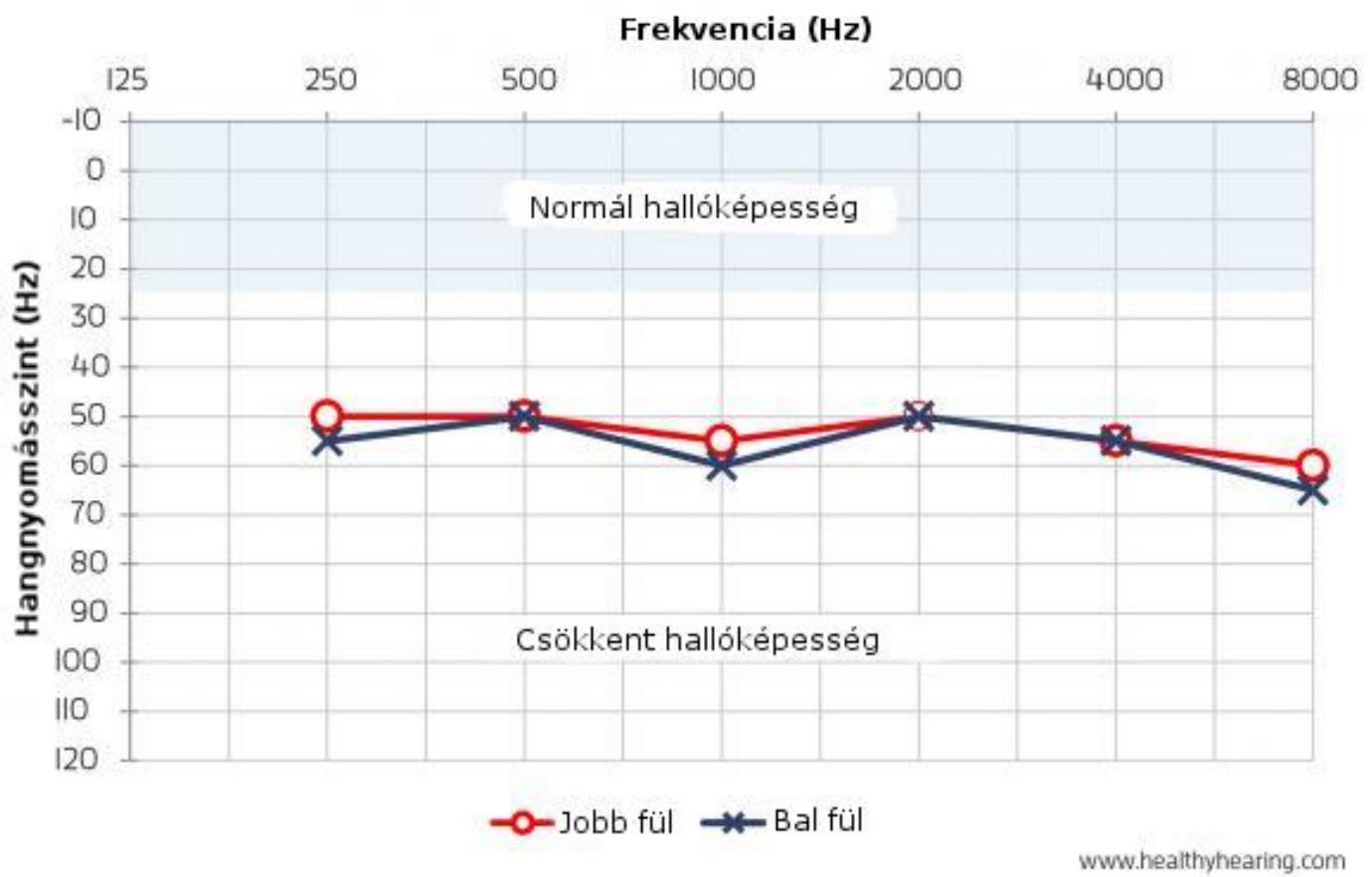

5. ábra. Mérsékelten halláskárosodott személy audiogramja [12]

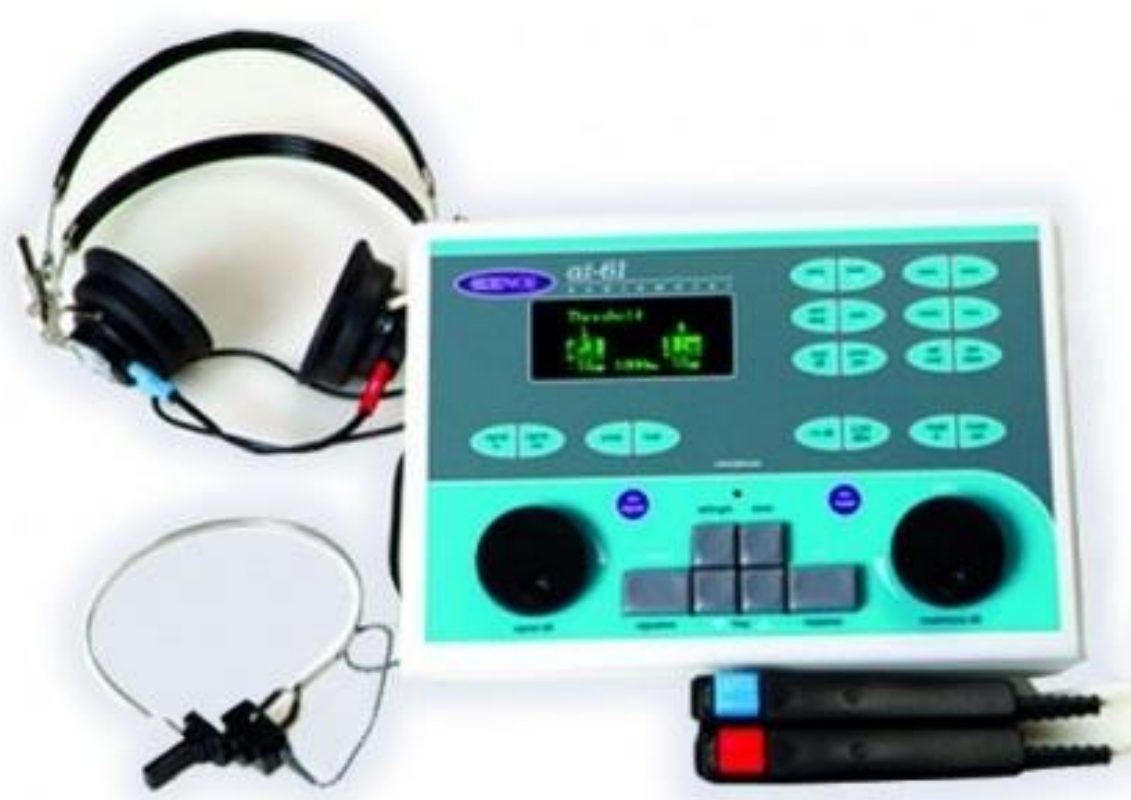

6. ábra. Klinikai audiométer AT 61 [13] 
A hallókészülékek kicsi elemmel müködő készülékek, amelyek a következő részekből épülnek fel:

- Mikrofon: fogadja a beérkező hangokat.

- Digitális hangfeldolgozó: feldolgozza és módosítja a bejövő jeleket a viselő előre beállított hallási szükségletei szerint.

- Erősítő: felerősíti a jeleket a szükséges hangerő eléréséhez.

- Hangszóró: reprodukálja a módosított és felerősített hangokat a viselő számára.

\subsection{A hallókészülékek típusai}

Fül mögött viselhető készülékek:

- RIC készülék (Receiver-in-the-canal): Az alkatrészek a fül mögött elhelyezett házban vannak, a hangszóró a hallójárat elején helyezkedik el, és egy alig látható vezeték köti össze a két elemet. Ez a típus esztétikuma miatt kedvelt, valamint több halláskárosodás típusra is alkalmazható. A RIC készülék a 7. ábrán látható.

- BTE készülék (Behind-the-ear): A BTE készülék három fő elemből áll: ház, fül felett átvezetett üreges cső és egy egyedi, fülhöz készített füldugó. Ezt a készüléket súlyos halláskárosodás esetén valamint gyerekeknél alkalmazzák, mert a házon kívül egyszerüen cserélhető elemekből készül. A BTE készülék a 8 . ábrán látható.

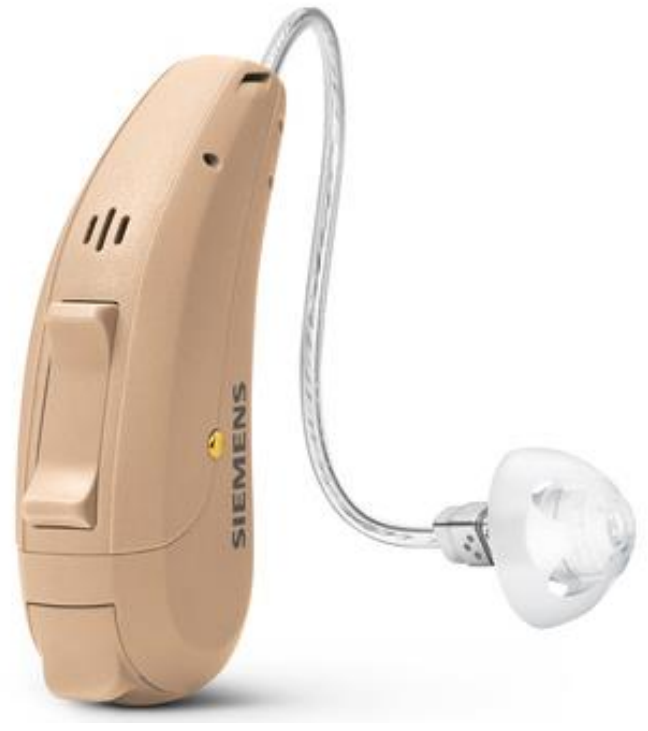

7. ábra. RIC hallókészülék [14]

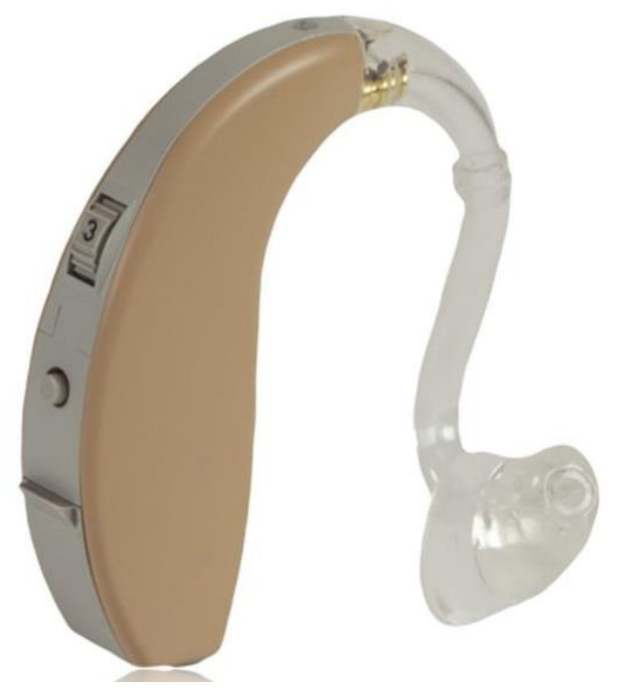

8. ábra. BTE hallókészülék [15]

\section{Egyedi formájú készülékek:}

- CIC készülék (Completely-in-the-canal): Kis méretü, a hallójárat elejében elhelyezett eszköz. Felnőttek számára készül, enyhe és mérsékelt halláskárosodás esetén alkalmazzák. Egyes modellek távirányítóval állítható hangerővel és programokkal rendelkeznek. A CIC készülék a 9. ábrán látható. 


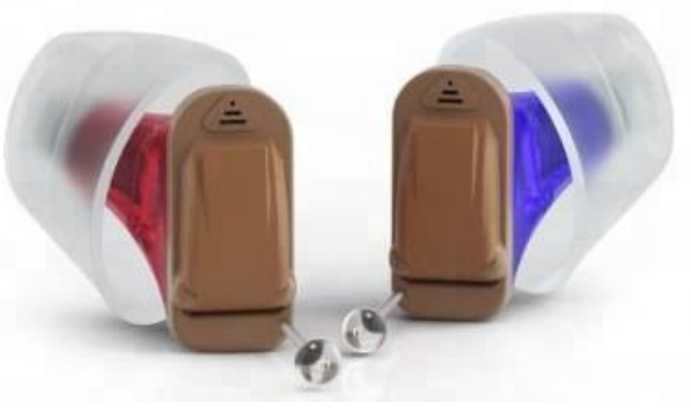

9. ábra. CIC hallókészülék [16]

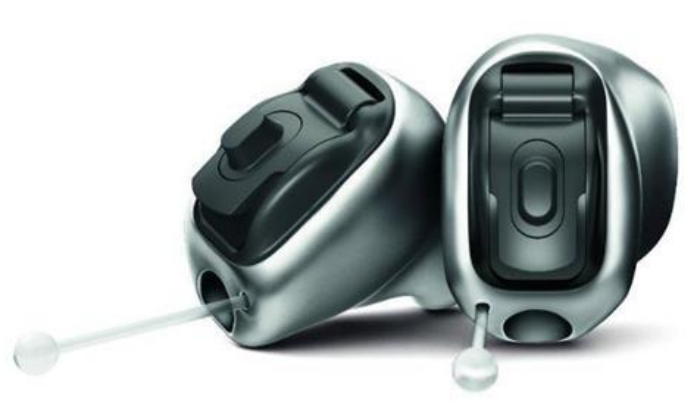

10. ábra. IIC hallókészülék [17]

- IIC készülék (Invisible-in-the-canal): A legkisebb hallókészülék típus, a hallójárat belsejében viselik, ezért közel észrevehetetlen. Enyhe és mérsékelt halláskárosodás esetén alkalmazzák. Kis mérete miatt az elem élettartama rövid. Az IIC készülék a 10. ábrán látható.

- ITE készülék (In-the-ear): A hallójárat elejében és a fülkagyló belsejében helyezkedik el. Egyszerüen felhelyezhető, így idősek is használhatják, valamint nagy mérete miatt szellőzőjárattal, hangerőszabályzóval is ellátott. Széles halláskárosodás tartományban alkalmazható, enyhétől egészen a súlyosig. Az ITE készülék a 11. ábrán látható.

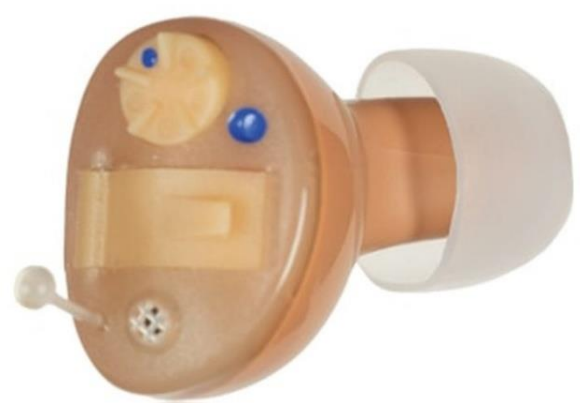

11. ábra. ITE hallókészülék [18]

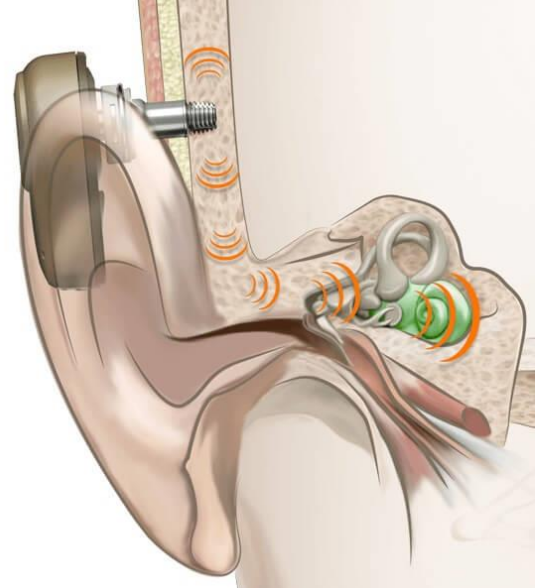

12. ábra. Csonton rögzitett hallókészülék [19]

- Csonton rögzített hallókészülék: sebészeti módon beültetnek egy vevőkészüléket a koponyába képzett 3-4mm-es furatba. A seb begyógyulása után a bőrből kinyúló csatlakozóra felhelyezik magát a készülékházat. Ez a típusú készülék hallásunk müködésének csontvezetéses részét használja ki. A készülék által feldolgozott hangokat rezgésként továbbítja a belső fül számára. Több halláskárosodás típusnál is alkalmazható: vezetéses, kevert valamint egyoldali süketség esetén is. Veszélyes beavatkozás, ugyanis a börnek egy idegen test körül kell begyógyulnia, ami könnyen elfertőződhet. A csonton rögzített hallókészülék a 12. ábrán látható.

A modern hallókészülékek különböző kiegészítőkkel rendelkezhetnek úgymint Bluetooth- 
kompatibilitás telefonokkal, televíziókkal, újratölthető elemek, távirányító és telecoil funkció.

Telecoil funkció [20]

A telecoil funkcióra figyelmeztető tábla a 13. ábrán látható. Ezeket a jelzéseket olyan intézményekben helyezik ki, ahol egy előre telepített berendezés a beszéd vagy zene átalakításából elektromágneses mezőt képez.

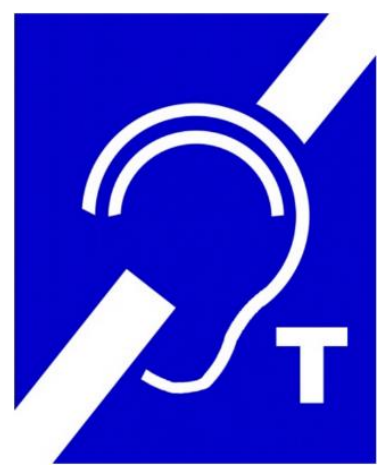

\section{3. ábra. Telecoil funkcióra figyelmeztetö tábla [21]}

A hallókészülékben egy beépített tekercs vevőként viselkedve érzékeli a mezőt és hangot képez a viselő fülében. Általában egy kapcsolót helyeznek el a hallókészüléken, ezzel lehet váltani a telecoil és a mikrofon funkció között. Hatalmas előnye, hogy csak az elektromos mező jeleit erősíti fel a hallókészülék, ezért háttérzaj nélkül jut el a hang a viselő fülében. Kiépített telecoil rendszer modernebb egyetemeken, koncerteken és repülőtereken található.

\section{Cochleáris implantátumok [22]}

A cochleáris implantátumok elnevezés az angol cochlea, azaz belső fül névből ered. A belső fül más néven csiga, ez tartalmazza a corti szervet, ami a hangrezgésekből ideg impulzusokat hoz létre. A cochleáris implantátum egy protézis, amit a bőr alá helyeznek el mütéti úton. Ehhez az implantátumhoz tartozik több kiszolgáló berendezés. Akkor alkalmazzák, ha súlyos, visszafordíthatatlan halláskárosodást kell javítani. Az implantátum nem adja vissza a normál hallást teljesen, viszont jobb eredményt ad az egyszerü hallókészülékekhez képest. Gyerekek számára ez a beszéd megértésében, elsajátításában játszik nagy szerepet, valamint egészséges hallásúakkal való közös oktatásban. Felnőtteknél a halláskárosodás miatti társadalmi elszigeteltség csökkentése és az általános kommunikáció javítása miatt hasznos. Az Advanced Bionics Cochleáris implantátuma a 14. ábrán látható.

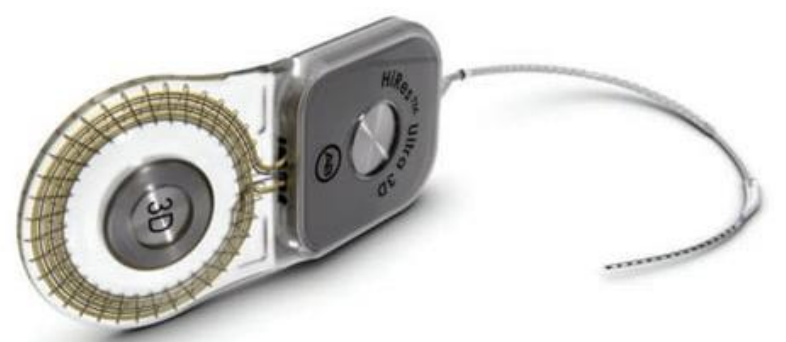

14. ábra. Advanced Bionics Cochleáris implantátum [23] 
A cochleáris implantátum egy rendszerben müködik, melynek elemei a 15. ábrán láthatók.

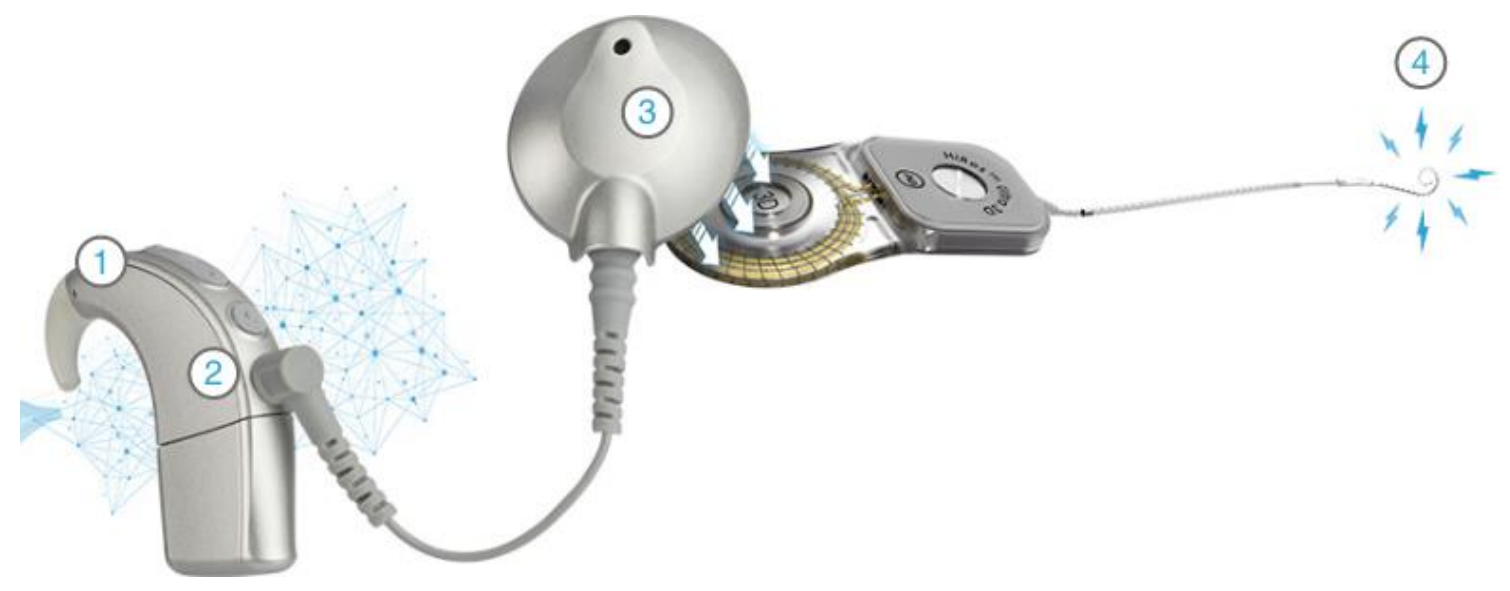

15. ábra. Advanced Bionics Cochleáris implantátum rendszer [24]

\section{A rendszer elemei:}

1. Mikrofon és adó: Kívülről a fülön viselt rész, amely összegyüjti és továbbítja a hangokat a beszédfeldolgozónak.

2. Beszédfeldolgozó: A beérkező hangokat digitális jelekké alakítja.

3. Jeltovábbító: A bőr külső felületén helyezkedik el, egy beépített mágnes tartja a bőr alá beültetett cochleáris implantátum felett. Ez továbbítja a jeleket a beültetett elektródának.

4. Elektróda: A fül mögött helyezkedik el, a koponya és a fejbőr között. A jeltovábbítóból kapott jelekkel stimulálja a hallóideget, a hallóideg impulzusokat küld az agy számára, amit az hangként dolgoz fel.

Az elektróda elhelyezése a 16. ábrán látható.

\subsection{Mütétet megelőző vizsgálatok}

Az implantációt egy vizsgálatsorozat előzi meg, amikor a fül-orr-gégész szakorvos és audiológus eldönti, hogy a páciens alkalmas-e a beültetetésre:

- Sebészi felmérés: a páciens fülét és hallásának kórtörténetét megvizsgálják, valamint elmagyarázzák a mütéti eljárást. 


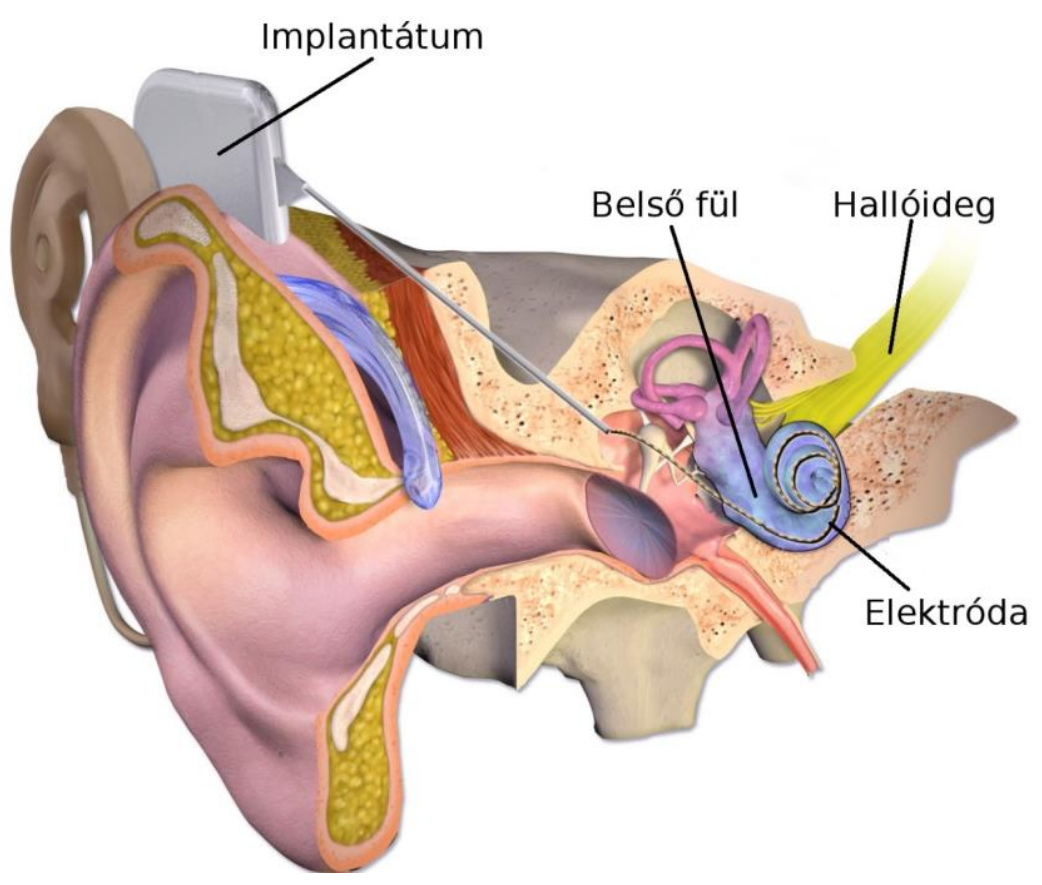

16. ábra. Cochleáris implantátum elektródájának helyzete a belsö fülben [25]

- CT vizsgálat: egy kétdimenziós röntgenfelvételt készítenek a belső fülröl. A CT vizsgálat lehetővé teszi az orvosnak, hogy felmérje a fül belső szerkezetét, valamint kiválaszthassa az implantációra alkalmasabb fület.

- Hallási felmérés: hallásvizsgálatot végeznek, és meghatározzák a páciens halláskárosodásának fajtáját és mértékét.

- Pszichológiai szürés: egy pszichológus konzultál a pácienssel a hallássérültséggel kapcsolatos érzéseiről, valamint az elvárásairól a cochleáris implantációval kapcsolatban.

- Implantációs konzultáció: Ekkor derül ki a vizsgálatsorozat összesítésénél, hogy a páciens alkalmas-e implantációra. Ha valaki alkalmasnak bizonyul, a várható hallásjavulásról és az implantációval járó korlátozásokról tájékoztatják, majd kiválasztják a számára megfelelő eszközt.

\subsection{Az implantáció}

A műtétet megelőzően aneszteziológus szakorvos elvégzi a szükséges vizsgálatokat. A mütétet altatásban végzik, és általánosságban három órán át tart. Elöször egy vágást végeznek a bőrön a fül mögött, szabaddá téve a halántékcsontot. Fúróval befogadó felületet és elektródavezető csatornát képeznek ki a halántékcsonton az elmozdulás megakadályozása érdekében. Ezt követően a sebész ráhelyezi az implantátumot a csontra. Az implantátum helye a 17. ábrán, az elektródavezető csatorna a 18. ábrán látható. 


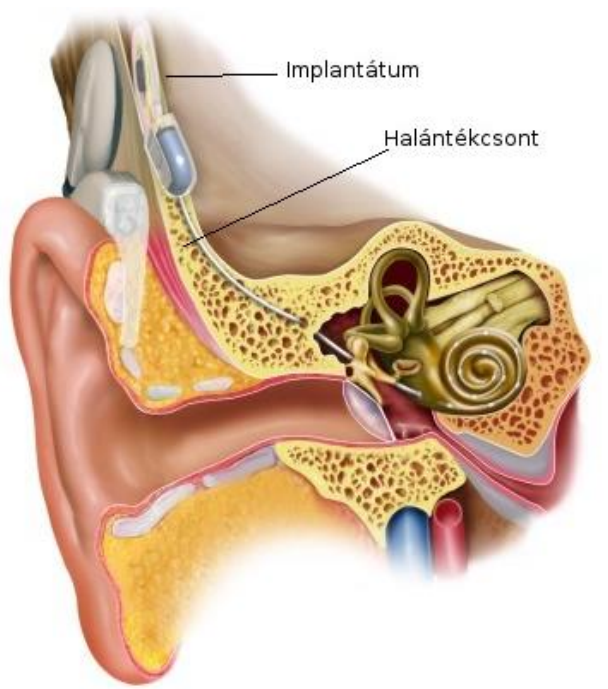

17. ábra. Cochleáris implantátum a halántékcsonton [26]

Az implantátum behelyezése után egy kisméretű átmenő furatot készítenek a koponya halántékcsontján a belső fül eléréséhez. A belső fülben a csigán is készítenek egy apró furatot, majd óvatosan belevezetik az elektródát a csiga belsejébe.

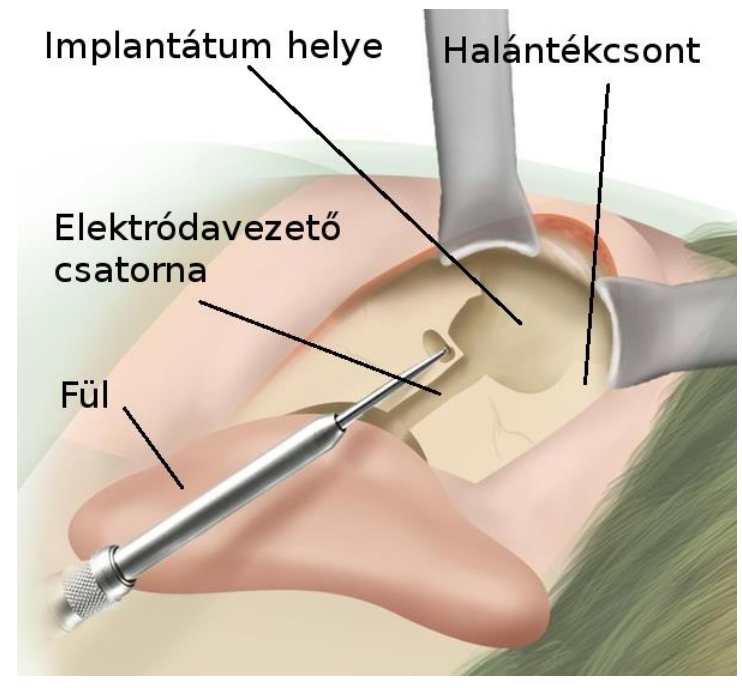

18. ábra. Elektródavezetö csatorna helye a halántékcsonton [27]

Az elektróda csatornában vezetésének a célja a külső mechanikai behatásoktól való védelem. Az elektródát ragasztópasztával rögzítik a csatornában, az implantátumot varratokkal rögzítik, majd bevarrják a sebet. Ezt követően egy steril kötözést helyeznek a sebre. A mütétet egy hónap felépülési idő követi, ezalatt otthon kell maradnia a páciensnek, amíg a bedagadt és érzékeny seb begyógyul. A cochleáris implantáció alacsony kockázatú mütétnek számít a belső fül többi beavatkozásához képest. 


\subsection{A cochleáris implantátum rendszer beállítása, ellenőrzése}

A beszédfeldolgozót négy héttel a műtét után az orvosnál teszik fel és próbálják ki először. Itt történik meg a programozás is, ami hosszabb időt vesz igénybe, 6-6 óra két napra szétosztva. Az implantátum üzembe helyezését követően időszakos vizsgálatokon kell részt venni, ahol ellenőrzik a készüléket, és mérik a hallóképességben elért javulást. Egy ilyen vizsgálat átlagosan 3 órán át tart.

\subsection{Hallóképesség változása az implantátummal}

Az idő előrehaladásával a kezelt személy hallóképessége javul az esetek többségében, de nem garantált. Fontos a rehabilitáció a lehető legjobb eredmény eléréséhez. Érdemes a készüléket az ébren töltött időben végig használni, minél többet kommunikálni a külvilággal. Az implantátummal ellátottak egy jobb minőségü életet élhetnek: zenét hallgathatnak, telefonálhatnak és társas életet élhetnek.

\section{Köszönetnyilvánítás}

A cikkben ismertetett kutató munka az EFOP-3.6.1-16-2016-00011 jelü „Fiatalodó és Megújuló Egyetem - Innovatív Tudásváros - a Miskolci Egyetem intelligens szakosodást szolgáló intézményi fejlesztése" projekt részeként - a Széchenyi 2020 keretében - az Európai Unió támogatásával, az Európai Szociális Alap társfinanszírozásával valósul meg.

\section{Irodalom}

[1] National Center for Biotechnology Information: https://www.ncbi.nlm.nih.gov/ books/NBK1434/ (letöltés dátuma: 2019.11.02)

[2] Wikipedia, Deaf history: https://en.wikipedia.org/wiki/Deaf_history\#cite_note-nad.org-23 (letöltés dátuma: 2019.10.18)

[3] Az emberi fül részei ábra: https://medikidskozpont.hu/wp-content/uploads/ 2019/06/F\%C3\% $\mathrm{BCl}$-anat\%C3\%B3mi\%C3\%A1ja-Medikids.png (letöltés dátuma: 2019.10.18)

[4] Lucile Packard Children's Hospital Stanford; Stanford Children's Health https://www.stanfordchildrens.org/en/topic/default?id=anatomy-and-physiology-of-the-ear-90P02025 (letöltés dátuma: 2019.09.25)

[5] National Institute on Deafness and Other Communication Disorders (NIDCD) https://www.nidcd.nih.gov/health/how-do-we-hear (letöltés dátuma: 2019.09.25)

[6] Encyclopaedia Britannica; Baziláris membrán ábra: https://www.britannica.com/science/basilarmembrane (letöltés dátuma: 2019.10.18)

[7] Department of Audiology and Speech Pathology; The University of Melbourne https://hearnet.org.au/hearing-loss/types-of-hearing-loss (letöltés dátuma: 2019.10.18)

[8] Department of Otolarynology Head and Neck Surgery; Columbia University http://www.entcolumbia.org/our-services/hearing-and-balance/hearing-aids (letöltés dátuma: 2019.10.22)

[9] Fültrombita ábra: https://static9.depositphotos.com/1041725/1099/v/950/depositphotos_ 10995212-stock-illustration-ear-trumpets-vintage-engraving.jpg (letöltés dátuma: 2019.10.22) 
[10] Fültrombita használata ábra: https://media.wnyc.org/i/800/0/1/85/1/beethoven-ear-trumpet.jpg (letöltés dátuma: 2019.09.28)

[11] Hallásspecialista Blog: https://hallasspecialista.blog.hu/2013/11/19/mire_jo_ez_a_furcsa_ koordinatarendszer_ismerjuk_meg_az_audiogramot (letöltés dátuma: 2019.11.05)

[12] Healthyhearing.com, https://www.healthyhearing.com/uploads/images/HH-audiogram.jpg (letöltés dátuma: 2019.11.05)

[13] Orvosimuszer.eu, http://orvosimuszer.eu/img/9324/UG447326/470x450/UG447326.jpg?time =1420797813 (letöltés dátuma: 2019.10.18)

[14] RIC készülék ábra: https://5.imimg.com/data5/FR/NQ/MY-31916564/siemens-orion-2-richearing-aid-500x500.jpg (letöltés dátuma: 2019.11.07)

[15] BTE készülék ábra: https://cdn11.bigcommerce.com/s-4u9yavrazq/images/stencil/ 1280x1280/products/113/432/ear-health-bte-digital-hearing-aid-ranger-7600_23049.

1554326679.jpg?c=2\&imbypass=on (letöltés dátuma: 2019.11.02)

[16] CIC készülék ábra: http://sc02.alicdn.com/kf/UTB8x4XfiFPJXKJkSahVq6xyzFXa1/UniqueSmall-Hearing-Aid-Hidden-in-the.jpg (letöltés dátuma: 2019.11.05)

[17] IIC készülék ábra: https://s26539.pcdn.co/wp-content/uploads/2017/03/virto-b-titanium.jpg (letöltés dátuma: 2019.10.18)

[18] ITE készülék ábra: https://cdn11.bigcommerce.com/s-4u9yavrazq/images/stencil/ 500x659/products/112/433/advanced-affordable-digital-ite-hearing-aid-earmate-4220_15729. 1554326721.jpg?c=2\&imbypass=on (letöltés dátuma: 2019.11.18)

[19] Csonton rögzített hallókészülék, https://www.happyearshearing.com/wp-content/uploads/2018/ 03/baha-what-is-bone-conduction-how-it-works.jpg (letöltés dátuma: 2019.10.28)

[20] Telecoil funkció, https://global.widex.com/en/blog/what-is-a-telecoil (letöltés dátuma: 2019.10.21)

[21] Telecoil ábra: https://global.widex.com/-/media/images/articles/blog/telecoil3.png?h=612\&w $=490 \&$ hash=651286F53C6035F686504460A6E91C612EBB494F\&la=en (letöltés dátuma: 2019.10.21)

[22] University of California San Francisco: https://www.ucsfhealth.org/treatments/cochlearimplants (letöltés dátuma: 2019.11.05)

[23] Advanced Bionics Cochleáris implantátum ábra: https://105b31079a1ba381f52eac2ec5114feb632a1114f20df0e72453.ssl.cf2.rackcdn.com/Page/59356407-6840-4e99-85410f8c0ad286aa/ABhiresultra3d.jpg (letöltés dátuma: 2019.11.03)

[24] Advanced Bionics Cochleáris rendszer részei ábra: https://advancedbionics.com/content/dam/ advancedbionics/Images/Global/Graphs\%20and\%20Illustrations/diagram-how-a-ci-works.jpg (letöltés dátuma: 2019.11.08)

[25] Cochleáris implantátum beépítése ábra: https://upload.wikimedia.org/wikipedia/commons/ 5/50/Blausen_0244_CochlearImplant_01.png (letöltés dátuma: 2019.11.07)

[26] Cochleáris implantátum a halántékcsonton ábra: https://auditoryneuroscience.com/sites/ default/files/MedElCochlearImplant.jpg (letöltés dátuma: 2019.10.18)

[27] Elektródavezető csatorna helye a halántékcsonton ábra: https://static.cambridge.org/binary/ version/id/urn:cambridge.org:id:binary:20180719101949391-0496:S0022215118000609:

S0022215118000609_fig2t.jpeg?pub-status=live (letöltés dátuma: 2019.10.09) 